\title{
The Dutch Miracle revisited. Discussion of Nog steeds een mirakel? De legitimiteit van het poldermodel in de eenentwintigste eeuw, edited by Maarten Keune.
}

\author{
Christoffer Green-Pedersen ${ }^{*}$
}

Almost twenty years ago, Jelle Visser and Anton Hemerijck published the book $A$ Dutch Miracle. Job Growth, Welfare Reform and Corporatism in the Netherlands with Amsterdam University Press. At that time, the Dutch economy was doing well compared to many other countries, which raised the question of what the Dutch were doing right and what others could learn from them. Visser and Hemerijck linked the miracle to Dutch corporatism - the polder model - and the learning capacity of the three actors involved: trade unions, employer organizations and the government. The learning capacity manifested itself in, among other things, wage moderation and welfare state reforms, which generated positive outcomes not least with regard to the labor market, i.e. low unemployment and job growth. Back in 1997, Visser and Hemerijck published an excellent book with the perfect timing.

The changes to the political and economic context of the Dutch economy since have been enormous and the financial crisis and its aftermath is probably the most significant change. So it is definitely time to revisit the Dutch miracle; actually it is surprising that nobody has done so before.

The book, which is edited by Maarten Keune, revisits the discussions raised by Visser and Hemerijck almost twenty years ago and sticks with their focus on the situation of Dutch corporatism. This is assessed using the concepts of output and input legitimacy and by looking at different forms of representation with regard to the actors involved in the polder model as laid out in the introduction. Various aspects of these questions are then taken up by the individual chapters. There is a lot to learn from the book about how Dutch corporatism and more broadly the Dutch political economy has developed.

As the introduction concludes, the Dutch miracle is over. The polder model still has some clear comparative advantages, but it is also challenged. In terms of output legitimacy, the Netherlands is doing fine in terms of for instance unemployment and public finances, but less well in terms of for instance the number of full-times jobs. In terms of input legitimacy, there are clear challenges for all actors involved. Trade unions are constantly losing members; corporatist bargaining typically takes place behind closed doors, and the legitimacy and transparency of the process are challenged.

* Christoffer Green-Pedersen is professor of Political Science at Aarhus University, Denmark. He is the author of The Politics of Justification. Party Competition and Welfare-State Retrenchment in Denmark and the Netherlands from 1982 to 1998, Amsterdam University Press 2002. 
Foreign readers can learn a lot about the Dutch policy economy from the book. Actually, one wishes that the book had been published in English and been accessible for a broader audience. Among the highlights are Ewald Engelen's chapter on the downside of the Dutch miracle, which focuses on the Dutch banking sector and the housing market. These were aspects of the Dutch economy that Visser and Hemerijck did not touch much upon, probably because they - as most other people - did not see them as particularly relevant before the financial crisis. Natascha van der Zwan's analysis of the development of the Dutch pension system is also highly informative; this aspect of the polder model was not in focus either twenty years ago.

A book like this can of course not cover all the aspects of the Dutch policy economy, and readers will always miss chapters on specific aspects. Let me mention three issues I wish the book had covered more intensively. The first one is the link between policies and outcomes. The Dutch economy did very well on some economic outcomes, but was this really the result of wage moderation and welfare reforms or was it simply luck? The role of 'fortuna' is discussed in the introduction, but a chapter or two that systematically assess the reasons for the success with focus on the role of corporatism, especially wage moderation and welfare state reform, would have been very interesting. It is no easy thing to investigate the causes of economic outcomes, but it deserves much attention considering the extent of political and academic discussions about which policy measures to use. Furthermore, it is often easier to analyze years later when data is available.

The link between policies and economic outcomes is crucial for the whole discussion about the legitimacy of the polder model. The book uses the concepts of input and output legitimacy, which were originally developed to analyze the legitimacy of democratic political systems. Using these concepts to discuss the development of Dutch corporatism provides the book with a well-functioning theoretical framework. However, is also slightly misleading as a corporatist system is not a democratic political system as such. Output legitimacy is even more crucial for a corporatist system than for a democratic system. If a democratic system is struggling with output legitimacy, the question is whether democratic reforms are necessary. If a corporatist system cannot deliver outputs that are beneficial for society, the question is whether we need corporatism at all. Further, we do to some extent accept that corporatist deals are made behind closed doors because this is necessary to reach agreement. On the other hand, transparency is crucial for any legislative process. In other words, given that output legitimacy must be the central form of legitimacy for a corporatist system, the book would have benefited from more detailed analyses of outputs as well as outcomes from the polder model. Is Dutch corporatism really so crucial for a positive economic outcomes in the Netherlands that reduced input legitimacy of the polder model is something to worry about?

The second issue relates to output, namely part-time work and its relationship to broader issues about the supply of daycare and female labor market participation. The introduction (p. 19) raises the question about how to evaluate the extensive use of part-time employment in the Netherlands compared to almost all other countries. This feature of the Dutch miracle was debated already twenty years ago 
and still raises important questions. Are part-time jobs actually a positive feature of the model as it facilitates the combination of family and work life or are they a problem as most people would prefer a full time job? To a non-Dutch reader, the extensive use of part-time jobs is one of the most striking features of the Dutch miracle and could have deserved a designated chapter.

The third issue is the development of the Dutch political system. The introduction (p. 35) cites Visser and Hemerijck that strong corporatism requires a strong government, which points to the role of the political system. When I looked at the Netherlands from an outside perspective in the late 1990s, a striking element of the 'Dutch Miracle' was the political system's ability to deliver a series of comprehensive welfare-state reforms while other countries were struggling to gain political support for such reforms. What was striking about Dutch politics in the 1990s was the broad political consensus on reforming the welfare state. This consensus manifested itself in the purple coalitions from 1994-2002 but had its origin in the centripetal nature of Dutch party competition due to the role of CDA and its predecessors. A lot has happened in Dutch party politics since then, and the book would have benefited from a chapter analyzing this. If corporatism needs a strong government, has the Netherlands then had a strong government since the 1990s? Nog steeds een mirakel? is an important and most welcome book. Considering all the attention the Dutch miracle rightly received some decades ago, it is justified to return to the theoretical and empirical questions that not least Visser and Hemerijck raised. The strong focus on evaluating Dutch corporatism using the concepts of input and output legitimacy gives the book a clear point of departure, but is also its limitation. At least the foreign reader would have liked more focus on the policies of the polder model and not least the effects of the policies. More focus on the political system could also have benefited the book. However, you cannot have it all and the book is recommendable to anyone who is interested in whether a miracle happened twenty years ago and in the Dutch political economy today. 